Asian Australas. J. Biosci. Biotechnol. 2020, 5 (1), 42-47

Asian-Australasian Journal of

Bioscience and Biotechnology

ISSN 2414-1283 (Print) 2414-6293 (Online)

www.ebupress.com/journal/aajbb

\title{
Article \\ Determination of pre-harvest interval for dimethoate and quinalphos in selected vegetables
}

Md. Sultan Ahmed*, Afroza Begum and Debasish Sarker

Division of Entomology, Bangladesh Agricultural Research Institute, Joydebpur, Gazipur-1701, Bangladesh

*Corresponding author: Md. Sultan Ahmed, Division of Entomology, Bangladesh Agricultural Research Institute, Joydebpur, Gazipur-1701, Bangladesh. E-mail: sultan_palbari@yahoo.com

Received: 01 April 2020/Accepted: 29 April 2020/ Published: 30 April 2020

\begin{abstract}
The study was undertaken to determine the pre-harvest interval (PHI) for dimethoate and quinalphos in cauliflower, eggplant and hyacinth bean depending on Maximum Residue Limit (MRL) set by European Union. Six supervised field trials were conducted and sprayed with the recommended dose (2 $\mathrm{ml} / \mathrm{L}$ of water) of each pesticide. Samples were collected at $0,1,2,3,4,5,6,7,8,9,10,11$ and 12 days after spray (DAS). The collected samples were analyzed using Gas Chromatography (GC) with Flame Thermionized Detector (FTD) for the determination of pesticide residue. The quantities of residue were above MRL up to 9 DAS for quinalphos in cauliflower, 7 DAS in hyacinth bean, 8 DAS in eggplant; 11 DAS for dimethoate in cauliflower, 10 DAS in hyacinth bean, and 9 DAS in eggplant. At 11 DAS, no residue was detected from any of the tested samples except dimethoate in cauliflower. The determined PHI for quinalphos was 10 DAS in cauliflower, 8 DAS in hyacinth bean and 9 DAS in eggplant. In case of dimethoate it was 12 DAS in cauliflower, 11 DAS in hyacinth bean and 10 DAS in eggplant.
\end{abstract}

Keywords: pesticide residue; PHI determination; cauliflower; hyacinth bean; eggplant

\section{Introduction}

Cauliflower, eggplant and hyacinth bean are commercial crop in Bangladesh. These vegetables are attacked by many insect pests. Insecticides are one of the major components of plant protection for the farmers of Bangladesh. Dimethoate (M.f. $\mathrm{C}_{6} \mathrm{H}_{12} \mathrm{NO}_{3} \mathrm{PS}_{2}$ ) and quinalphos (M.f. $\mathrm{C}_{10} \mathrm{H}_{5} \mathrm{Cl}_{2} \mathrm{NO}_{2}$ ) are an organophosphorus insecticide and acaricide. These are plays an important role for the control of chewing, sucking and some borer pests of vegetables. The pattern of insecticide usage in vegetables led to assume that major vegetable growing areas of Bangladesh should be overloaded with insecticide residue, since insecticides are being used by vegetable farmers irrationally, in some occasions whimsically. It was understood from farmers' interview that they use insecticides irrationally and indiscriminately (Anonymous, 2001; Ahmed et al., 2005). A considerable number of farmers sell vegetables immediate after spray or at an interval of 0-2 days after spray (Anonymous, 2000). This led to assume that over-sprayed vegetable consumers might face health hazards and environment might be over loaded with insecticide residue. Pesticide being toxic can become a potential hazard to the manufacturers, the user, the public at large and the environment. Pesticide can produce negative impacts, both social and private (Antle and Pingali, 1994). Due to lack of education, the farmers of our country do not follow the prescribed dosages and use pesticides at any stage of the crop without any awareness of the residues and their ill effects on human health. The treated fruits and vegetables are harvested without taking into account of the withholding period. Every pesticide has a withholding period or pre-harvest interval (PHI), which is defined as the number of days required to lapse, between the date of final pesticide application and harvest, for residues to fall below the tolerance level established for that crop or for a similar food type. Food products become safe for consumption only after withholding period has lapsed. The PHI differs from pesticide to pesticide and crop to crop. So, we have to re-set the pre harvest interval on the consideration of our environmental conditions. 
Considering these, the present study was undertaken to re-set the PHI for dimethoate and quinalphos in selected vegetables grown in Bangladesh.

\section{Materials and Methods}

The standard for dimethoate and quinalphos were obtained from Sigma-Aldrich Laborchemikalien, Gmbh P O Box-100262 D-30918, Seelze, Germany via Bangladesh Scientific Pvt. Itd. Dhaka, Bangladesh. Standards of both the insecticides contained $99.6 \%$ purity. Marketable size of cauliflower, hyacinth bean and eggplant were collected from supervised field trials at $0,1,2,3,4,5,6,7,8,9,10,11$ and 12 days after spray (DAS) which (dimethoate and quinalphos) were sprayed with @ $2 \mathrm{ml} / \mathrm{L}$ of water. The formulated product of dimethoate was Tafgor 40EC and quinalphos was Kinalux 25EC. The purity of formulated insecticides were tested in the pesticide analytical laboratory and found to be $100 \%$ pure.

\subsection{Extraction, separation and cleanup}

Field collected samples $(\geq 250 \mathrm{~g})$ were grounded thoroughly with the meat grinder (Handmixer M-122, Bamix, Switzerland). A sub sample of $20 \mathrm{~g}$ was taken into a wide mouth jar then $100 \mathrm{ml}$ of hexane was added to it. Sodium sulphate $\left(\mathrm{Na}_{2} \mathrm{SO}_{4}\right)$ was also added with sample until water was removed from the sample. The mixture was then macerated with high-speed homogenizer (Ultraturax, IKA T18 basic, Germany) for 2 minutes. The homogenized material was then poured into $250 \mathrm{ml}$ conical flask and placed into the shaker (Orbital Shaking Incubator, Rexmed, Sweden) for 12 hrs continuous shaking. After shaking, the slurry was filtered through a Buchner funnel with suction. The flask and filter cakes were rinsed with $25 \mathrm{ml}$ of hexane each. The filtrate was then transferred into $250 \mathrm{ml}$ round bottom flask and was dried to $5 \mathrm{ml}$ by evaporation using a rotary vacuum evaporator (Laborota-4001, Heidolph, Germany). The concentrated filtrate was then transferred into $500 \mathrm{ml}$ separatory funnel making $10 \mathrm{ml}$ in volume. Around $20 \mathrm{ml}$ methanol was added with $10 \mathrm{ml}$ filtrate and shaked vigorously for 5 minutes. After shaking, the separatory funnel was set on stand and kept undisturbed for 5 minutes. Then the clear part of the solution from the bottom of the separatory funnel was collected in a vial which was then centrifuged at $1200 \mathrm{rpm}$ for 5 minutes (Laboratory Centrifuges, Sigma-3K30, Germany). After centrifuge, supernatant was collected for injection in Gas Chromatography.

\subsection{Operating condition of GC-FTD}

The concentrated extracts were subjected to analysis by Gas Chromatography (GC-2010 Shimadzu). For Organophosphorus insecticide (dimethoate and quinalphos), FTD (Flame Thermionized Detector) was used. Separation was done by ATTM-1 capillary column $(30 \mathrm{~m}$ length, $0.25 \mathrm{~mm}$ inner diameter and $0.25 \mu \mathrm{m}$ film thickness). Helium was used as carrier and make up gas. Injection temperature was $260^{\circ} \mathrm{C}$ and detector temperature was $280^{\circ} \mathrm{C}$, respectively and the column oven temperature was programmed. The column oven initial temperature was $160^{\circ} \mathrm{C}$ which went upto $240^{\circ} \mathrm{C}$ following $8 \mathrm{~min}$ incremental time. Current was $0.5 \mathrm{pA}$, Makeup flow was $30 \mathrm{ml} / \mathrm{min}, \mathrm{H}_{2}$ Flow was $1.5 \mathrm{~mL} / \mathrm{min}$ and Air flow was $145 \mathrm{ml} / \mathrm{min}$, respectively. All the injections $(2 \mu \mathrm{L})$ were done in split mode. The total run time was $12 \mathrm{~min}$. Identification of the analyte in the sample was done by compering the retention time of the corresponding calibration standard and quantification was done by external calibration curves maid with 5 point calibration standard.

Previous to the injection of the sample extract, standard solutions of different concentrations of both pesticide groups were prepared and injected with the above instrument parameters. The samples were calibrated (retention time, peak area etc.) against three to four pointed calibration curve of standard solution of concerned pesticide. Each peak was characterized by its retention time. Sample results were expressed in $\mathrm{mg} / \mathrm{kg}$ automatically by the GC software which represented the concentration of the final volume injected.

\subsection{Determination of pre-harvest interval}

The amount of residues in all of the collected samples for both the pesticide and every vegetable were calculated following the described procedures. Then the sampling day which was next following MRL was selected. That selected day was chosen as PHI, since the level of residue on that day was below MRL.

\section{Results}

\subsection{Amount of residue of quinalphos estimated from cauliflower, hyacinth bean and eggplant}

The cauliflower, hyacinth bean and eggplant samples containing quinalphos residues were analyzed using the GC-FT D with set parameters. The results obtained from this analysis are summarized in Table 1-3. 
Table 1. Quantity of residue of quinalphos (Kinalux 25EC) estimated from cauliflower.

\begin{tabular}{llllllll}
\hline $\begin{array}{l}\text { Days after } \\
\text { spraying }\end{array}$ & $\begin{array}{l}\text { Sample } \\
\text { weight } \\
(\mathbf{g})\end{array}$ & $\begin{array}{l}\text { Total volume } \\
\text { prepared } \\
(\mathbf{m l})\end{array}$ & $\begin{array}{l}\text { Injected } \\
\text { volume } \\
(\boldsymbol{\mu l})\end{array}$ & $\begin{array}{l}\text { Concentration } \\
\text { obtained in final } \\
\text { volume }(\mathbf{m g} / \mathbf{k g})\end{array}$ & $\begin{array}{l}\text { Amount } \\
\text { Residue } \\
(\mathbf{m g} / \mathbf{k g})\end{array}$ & $\begin{array}{l}\text { Maximum } \\
\text { Residue Limit; } \\
\text { MRL (mg/kg) }\end{array}$ \\
\hline 0 & 20 & 10 & 2 & 13.380 & 6.690 & 0.01 \\
1 & 20 & 10 & 2 & 10.256 & 5.128 & \\
2 & 20 & 10 & 2 & 8.640 & 4.320 & \\
3 & 20 & 10 & 2 & 5.810 & 2.905 & \\
4 & 20 & 10 & 2 & 2.864 & 1.432 & \\
5 & 20 & 10 & 2 & 1.734 & 0.867 & \\
6 & 20 & 10 & 2 & 0.924 & 0.462 & \\
7 & 20 & 10 & 2 & 0.460 & 0.230 & \\
8 & 20 & 10 & 2 & 0.130 & 0.065 & \\
9 & 20 & 10 & 2 & 0.046 & 0.023 & \\
10 & 20 & 10 & 2 & ND & ND & \\
\hline
\end{tabular}

The residue of quinalphos was detected up to 9 DAS. The quantities of residues were $6.690 \mathrm{mg} / \mathrm{kg}, 5.128$ $\mathrm{mg} / \mathrm{kg}, 4.320 \mathrm{mg} / \mathrm{kg}, 2.905 \mathrm{mg} / \mathrm{kg}, 1.432 \mathrm{mg} / \mathrm{kg}, 0.867 \mathrm{mg} / \mathrm{kg}, 0.462 \mathrm{mg} / \mathrm{kg}, 0.230 \mathrm{mg} / \mathrm{kg} 0.065 \mathrm{mg} / \mathrm{kg}$ and $0.023 \mathrm{mg} / \mathrm{kg}$ at $0,1,2,34,5,6,7,8$ and 9 DAS, respectively. All of the tested samples had quinalphos residues which were above MRL set by European Union. No residue was detected at 10 DAS. So, the PHI of quinalphos for cauliflower can be selected at 10 DAS.

Table 2. Quantity of residue of quinalphos (Kinalux 25EC) estimated from hyacinth bean.

\begin{tabular}{llllllll}
\hline $\begin{array}{l}\text { Days after } \\
\text { spraying }\end{array}$ & $\begin{array}{l}\text { Sample } \\
\text { weight } \\
(\mathbf{g})\end{array}$ & $\begin{array}{l}\text { Total volume } \\
\text { prepared } \\
(\mathbf{m l})\end{array}$ & $\begin{array}{l}\text { Injected } \\
\text { volume } \\
(\boldsymbol{\mu l})\end{array}$ & $\begin{array}{l}\text { Concentration } \\
\text { obtained in final } \\
\text { volume (mg/kg) }\end{array}$ & $\begin{array}{l}\text { Amount } \\
\text { Residue } \\
(\mathbf{m g} / \mathbf{k g})\end{array}$ & $\begin{array}{l}\text { Maximum } \\
\text { Residue Limit; } \\
\text { MRL (mg/kg) }\end{array}$ \\
\hline 0 & 20 & 10 & 2 & 7.520 & 3.760 & 0.01 \\
1 & 20 & 10 & 2 & 2.960 & 1.480 & \\
2 & 20 & 10 & 2 & 1.316 & 0.658 & \\
3 & 20 & 10 & 2 & 0.792 & 0.396 & \\
4 & 20 & 10 & 2 & 0.402 & 0.201 & \\
5 & 20 & 10 & 2 & 0.184 & 0.092 & \\
6 & 20 & 10 & 2 & 0.112 & 0.056 & \\
7 & 20 & 10 & 2 & 0.058 & 0.029 & \\
8 & 20 & 10 & 2 & ND & ND & \\
\hline
\end{tabular}

Residue of quinalphos in hyacinth bean could be detected up to 7 DAS and all of the quantities were above MRL which were $3.760 \mathrm{mg} / \mathrm{kg}, 1.480 \mathrm{mg} / \mathrm{kg}, 0.658 \mathrm{mg} / \mathrm{kg}, 0.396 \mathrm{mg} / \mathrm{kg}, 0.201 \mathrm{mg} / \mathrm{kg}, 0.092 \mathrm{mg} / \mathrm{kg}, 0.056$ $\mathrm{mg} / \mathrm{kg}$ and $0.029 \mathrm{mg} / \mathrm{kg}$ at $0,1,2,3,4,5,6$ and 7 DAS, respectively. Sample of 8 DAS contained no detectable residue. So, the PHI of quinalphos for hyacinth bean can be selected at 8 DAS.

Table 3. Quantity of residue of quinalphos (Kinalux 25EC) estimated from eggplant.

\begin{tabular}{lllllll}
\hline $\begin{array}{l}\text { Days after } \\
\text { spraying }\end{array}$ & $\begin{array}{l}\text { Sample } \\
\text { weight } \\
(\mathbf{g})\end{array}$ & $\begin{array}{l}\text { Total volume } \\
\text { prepared } \\
(\mathbf{m l})\end{array}$ & $\begin{array}{l}\text { Injected } \\
\text { volume } \\
(\boldsymbol{\mu l})\end{array}$ & $\begin{array}{l}\text { Concentration } \\
\text { obtained in final } \\
\text { volume (mg/kg) }\end{array}$ & $\begin{array}{l}\text { Amount } \\
\text { Residue } \\
(\mathbf{m g} / \mathbf{k g})\end{array}$ & $\begin{array}{l}\text { of } \\
\text { Residue Limit; } \\
\text { MRL (mg/kg) }\end{array}$ \\
\hline 0 & 20 & 10 & 2 & 14.032 & 7.016 & 0.01 \\
1 & 20 & 10 & 2 & 8.764 & 4.382 & \\
2 & 20 & 10 & 2 & 5.520 & 2.760 & \\
3 & 20 & 10 & 2 & 3.608 & 1.804 & \\
4 & 20 & 10 & 2 & 1.912 & 0.956 & \\
5 & 20 & 10 & 2 & 1.362 & 0.681 & \\
6 & 20 & 10 & 2 & 0.816 & 0.408 & \\
7 & 20 & 10 & 2 & 0.458 & 0.229 & \\
8 & 20 & 10 & 2 & 0.056 & 0.028 & \\
9 & 20 & 10 & 2 & ND & ND & \\
\hline
\end{tabular}


The results revealed that residues of quinalphos were detected up to 8 DAS in eggplant. The detected quantities were $7.016 \mathrm{mg} / \mathrm{kg}, 4.382 \mathrm{mg} / \mathrm{kg}, 2.760 \mathrm{mg} / \mathrm{kg}, 1.804 \mathrm{mg} / \mathrm{kg}, 0.956 \mathrm{mg} / \mathrm{kg}, 0.681 \mathrm{mg} / \mathrm{kg}, 0.408 \mathrm{mg} / \mathrm{kg}$ and 0.229 $\mathrm{mg} / \mathrm{kg}$ and $0.028 \mathrm{mg} / \mathrm{kg}$ at $0,1,2,3,4,5,6,7$ and 8 DAS, respectively. All the tested samples which had quinalphos residues were of above the MRL set by European Union. No residue was detected at 9 DAS. So, the PHI of quinalphos for eggplantl can be selected at 9 DAS.

\subsection{Amount of residue of dimethoate estimated from cauliflower, hyacinth bean and eggplant}

The cauliflower, eggplant and hyacinth bean samples containing dimethoate residues were analyzed using the GC-FTD with set parameters. The results obtained from this analysis are summarized in Table 4-6.

Table 4. Quantity of residue of dimethoate (Tafgor 40EC) estimated from cauliflower.

\begin{tabular}{|c|c|c|c|c|c|c|}
\hline $\begin{array}{l}\text { Days after } \\
\text { spraying }\end{array}$ & $\begin{array}{l}\text { Sample } \\
\text { weight } \\
\text { (g) }\end{array}$ & $\begin{array}{l}\text { Total volume } \\
\text { prepared } \\
(\mathrm{ml})\end{array}$ & $\begin{array}{l}\text { Injected } \\
\text { volume } \\
(\mu \mathrm{l})\end{array}$ & $\begin{array}{l}\text { Concentration } \\
\text { obtained in final } \\
\text { volume (mg/kg) }\end{array}$ & $\begin{array}{l}\text { Amount of } \\
\text { Residue } \\
\text { (mg/kg) }\end{array}$ & $\begin{array}{l}\text { Maximum } \\
\text { Residue Limit; } \\
\text { MRL (mg/kg) }\end{array}$ \\
\hline 0 & 20 & 10 & 2 & 36.058 & 18.029 & 0.01 \\
\hline 1 & 20 & 10 & 2 & 31.812 & 15.906 & \\
\hline 2 & 20 & 10 & 2 & 24.196 & 12.098 & \\
\hline 3 & 20 & 10 & 2 & 18.804 & 9.402 & \\
\hline 4 & 20 & 10 & 2 & 13.986 & 6.993 & \\
\hline 5 & 20 & 10 & 2 & 8.638 & 4.319 & \\
\hline 6 & 20 & 10 & 2 & 3.410 & 1.705 & \\
\hline 7 & 20 & 10 & 2 & 0.938 & 0.469 & \\
\hline 8 & 20 & 10 & 2 & 0.612 & 0.306 & \\
\hline 9 & 20 & 10 & 2 & 0.280 & 0.140 & \\
\hline 10 & 20 & 10 & 2 & 0.124 & 0.062 & \\
\hline 11 & 20 & 10 & 2 & 0.036 & 0.018 & \\
\hline 12 & 20 & 10 & 2 & ND & ND & \\
\hline
\end{tabular}

Residue of dimethoate was detected up to $11 \mathrm{DAS}$ in cauliflower. The detected quantities were $18.029 \mathrm{mg} / \mathrm{kg}$, $15.906 \mathrm{mg} / \mathrm{kg}, 12.098 \mathrm{mg} / \mathrm{kg}, 9.402 \mathrm{mg} / \mathrm{kg}, 6.993 \mathrm{mg} / \mathrm{kg}, 4.319 \mathrm{mg} / \mathrm{kg}, 1.705 \mathrm{mg} / \mathrm{kg}, 0.569 \mathrm{mg} / \mathrm{kg}$ and 0.306 $\mathrm{mg} / \mathrm{kg}, 0.140 \mathrm{mg} / \mathrm{kg}, 0.062 \mathrm{mg} / \mathrm{kg}$ and $0.018 \mathrm{mg} / \mathrm{kg}$, at $0,1,2,3,4,5,6,7,8,9,10$ and $11 \mathrm{DAS}$, respectively. All of the quantities were above MRL set by European Union. No residue was detected at 12 DAS. So, the PHI of dimethoate for cauliflower can be selected at 12 DAS.

Table 5. Quantity of residue of dimethoate (Tafgor 40EC) estimated from hyacinth bean.

\begin{tabular}{llllllll}
\hline $\begin{array}{l}\text { Days after } \\
\text { spraying }\end{array}$ & $\begin{array}{l}\text { Sample } \\
\text { weight } \\
(\mathbf{g})\end{array}$ & $\begin{array}{l}\text { Total volume } \\
\text { prepared } \\
(\mathbf{m l})\end{array}$ & $\begin{array}{l}\text { Injected } \\
\text { volume } \\
(\boldsymbol{\mu l})\end{array}$ & $\begin{array}{l}\text { Concentration } \\
\text { obtained in final } \\
\text { volume (mg/kg) }\end{array}$ & $\begin{array}{l}\text { Amount } \\
\text { Residue } \\
(\mathbf{m g} / \mathbf{k g})\end{array}$ & $\begin{array}{l}\text { of } \\
\text { Residue Limit; } \\
\text { MRL (mg/kg) }\end{array}$ \\
\hline 0 & 20 & 10 & 2 & 22.522 & 11.261 & 0.01 \\
1 & 20 & 10 & 2 & 19.900 & 9.950 & \\
2 & 20 & 10 & 2 & 14.136 & 7.068 & \\
3 & 20 & 10 & 2 & 10.024 & 5.012 & \\
4 & 20 & 10 & 2 & 7.018 & 3.509 & \\
5 & 20 & 10 & 2 & 2.520 & 1.260 & \\
6 & 20 & 10 & 2 & 1.092 & 0.546 & \\
7 & 20 & 10 & 2 & 0.308 & 0.154 & \\
8 & 20 & 10 & 2 & 0.128 & 0.064 & \\
9 & 20 & 10 & 2 & 0.078 & 0.039 & \\
10 & 20 & 10 & 2 & 0.024 & 0.012 & \\
11 & 20 & 10 & 2 & ND & ND & \\
\hline
\end{tabular}

Form the Table 5, it was observed that dimethoate residue was detected in the hyacinth bean sample up to 10 DAS and the quantities were $11.261 \mathrm{mg} / \mathrm{kg}, 9.950 \mathrm{mg} / \mathrm{kg}, 7.068 \mathrm{mg} / \mathrm{kg}, 5.012 \mathrm{mg} / \mathrm{kg}, 3.509 \mathrm{mg} / \mathrm{kg}, 1.260 \mathrm{mg} / \mathrm{kg}$ and $0.546 \mathrm{mg} / \mathrm{kg}, 0.154 \mathrm{mg} / \mathrm{kg}, 0.064 \mathrm{mg} / \mathrm{kg}, 0.039 \mathrm{mg} / \mathrm{kg}$ and $0.012 \mathrm{mg} / \mathrm{kg}$ at $0,1,2,3,4,5,6,7,8,9$ and 10 DAS, respectively. The quantities decreased down gradually from 0 DAS to 10 DAS and all the detected residue 
levels were above MRL set by European Union. No residue was detected at 11 DAS. So, the PHI of dimethoate for hyacinth bean can be selected at 11 DAS.

Table 6. Quantity of residue of dimethoate (Tafgor 40EC) estimated from eggplant.

\begin{tabular}{llllllll}
\hline $\begin{array}{l}\text { Days after } \\
\text { spraying }\end{array}$ & $\begin{array}{l}\text { Sample } \\
\text { weight } \\
(\mathbf{g})\end{array}$ & $\begin{array}{l}\text { Total volume } \\
\text { prepared } \\
(\mathbf{m l})\end{array}$ & $\begin{array}{l}\text { Injected } \\
\text { volume } \\
(\boldsymbol{\mu l})\end{array}$ & $\begin{array}{l}\text { Concentration } \\
\text { obtained in final } \\
\text { volume }(\mathbf{m g} / \mathbf{k g})\end{array}$ & $\begin{array}{l}\text { Amount } \\
\text { Residue } \\
(\mathbf{m g} / \mathbf{k g})\end{array}$ & $\begin{array}{l}\text { of } \\
\text { Residue Limit; } \\
\text { MRL (mg/kg) }\end{array}$ \\
\hline 0 & 20 & 10 & 2 & 13.842 & 6.921 & 0.01 \\
1 & 20 & 10 & 2 & 10.602 & 5.301 & \\
2 & 20 & 10 & 2 & 7.928 & 3.964 & \\
3 & 20 & 10 & 2 & 3.340 & 1.670 & \\
4 & 20 & 10 & 2 & 1.522 & 0.761 & \\
5 & 20 & 10 & 2 & 1.058 & 0.529 & \\
6 & 20 & 10 & 2 & 0.494 & 0.247 & \\
7 & 20 & 10 & 2 & 0.208 & 0.104 & \\
8 & 20 & 10 & 2 & 0.106 & 0.053 & \\
9 & 20 & 10 & 2 & 0.044 & 0.022 & \\
10 & 20 & 10 & 2 & ND & ND & \\
\hline
\end{tabular}

The results revealed that residue of dimethoate could be detected up to 9 DAS in eggplant. All of the detected quantities were above MRL and these were $6.921 \mathrm{mg} / \mathrm{kg}, 5.301 \mathrm{mg} / \mathrm{kg}, 3.960 \mathrm{mg} / \mathrm{kg}, 1.670 \mathrm{mg} / \mathrm{kg}, 0.761 \mathrm{mg} / \mathrm{kg}$, $0.529 \mathrm{mg} / \mathrm{kg}, 0.247 \mathrm{mg} / \mathrm{kg}, 0.104 \mathrm{mg} / \mathrm{kg}, 0.053 \mathrm{mg} / \mathrm{kg}$ and $0.022 \mathrm{mg} / \mathrm{kg}$ at $0,1,2,3,4,5,6,7,8$ and 9 DAS, respectively. But the sample of 10 DAS, no residue was detected. So, the PHI of dimethoate for eggplant can be selected at 10 DAS.

\section{Discussion}

The residue of quinalphos was detected up to 9 DAS in cauliflower, 7 DAS in hyacinth bean and 8 DAS in eggplant. The tested samples had quinalphos residue ranged from7.016-0.023 mg $/ \mathrm{kg}$ which were above MRL set by European Union. No residue was detected at 10 DAS in cauliflower, 8 DAS in hyacinth bean and 9 DAS in eggplant. The PHI can be selected for quinalphos at 10 DAS in cauliflower, 8 DAS in hyacinth bean and 9 DAS in eggplant. Residue of dimethoate was detected up to 11 DAS in cauliflower, 10 DAS in hyacinth bean and 9 DAS in eggplant. The levels of dimethoate residue ranged from 18.029-0.012 mg/kg which were above MRL set by European Union. Sample of 12 DAS in cauliflower, 11 DAS in hyacinth bean and 10 DAS in eggplant did not show any detectable residue. The PHI for dimethoate at 12 DAS in cauliflower, 11 DAS in hyacinth bean and 10 DAS in eggplant. The PHI of tested pesticides were varied in crop to crop because of the plant behavior might be related to physic-chemical properties of pesticide degradation (Virgina and Bajet, 1996). Ahmed et al. (2011) reported that quinalphos residue detected up to 10 DAS in cauliflower and brinjal and 7 DAS in bean and the quantities were above MRL up to 7 DAS. The PHI for quinalphos might be selected 10 DAS in cauliflower, bean and brinjal. But it differed from Kabir et al. (2008) who observed the residue of quinalphos detected up to 6 DAS in yard long bean and the quantity was above MRL at 4 DAS. The findings of the study also agreed with the observation of Prodhan et al. (2018) they found PHI for quinalphos at 7 DAS in yard long bean, 10 DAS in eggplant and 12 DAS in cabbage.

\section{Conclusions}

The present study selected the pre-harvest interval (PHI) of dimethoate and quinalphos in three different vegetables. The determined PHI for quinalphos was 10 DAS in cauliflower, 8 DAS in hyacinth bean and 9 DAS in eggplant. But for dimethoate it was 12 DAS in cauliflower, 11 DAS in hyacinth bean and 10 DAS in eggplant. The results of the study will help the farmers for safe food production.

\section{Conflict of interest}

None to declare. 


\section{References}

Ahmed MS, MA Sardar, MA Haque and KH Kabir, 2005. A survey on the pattern of insecticidal usage for the protection of brinjal (Solanum melongena) from the attack of insect pests in Jessore. Bangladesh J. Zool., 33: 57-63.

Ahmed MS, MA Sardar, M Ahmad and KH Kabir, 2011. Qualitative and quantitative analysis of selected insecticide and detection of their residues from vegetables. Ph.D. Thesis: Department of Entomology, Bangladesh Agricultural University, Mymensingh. 102 pp.

Anonymous, 2000. Annual report 1999-2000, Entomology Division, Bangladesh Agricultural Research Institute, Joydebpur, Gazipur, Bangladesh

Anonymous, 2001. Coordinated research on insecticide residue and resistance in major vegetables grown in Bangladesh. Report on Contact Research Project, BARC, BARI,

Antle JM and PL Pingali, 1994. Pesticides, productivity and farmer health: a Philippine case study. Am. J. Agric. Econ., 76: 418-430.

EU pesticide data base. 2018. https://ec.europa.eu/food/plant/pesticides/eu-pesticides-database.

Kabir KH, MA Rahman, MS Ahmed, MDH Prodhan and MW Akon, 2008. Quantitative analysis of some common insecticides used against vegetable insect pests. Bangladesh J. Agriculturist., 1: 259-264.

Prodhan MDH, MW Akon and SN Alam, 2018. Determination of pre-harvest interval for quinalphos, malathion, diazinon and cypermethrin in major vegetables. J. Environ. Anal. Toxicol., 8: 553.

Virgina RO and CM Bajet, 1996. Pesticides in the Philippine environment. In: Proceedings. Anniversary and Annual Scientific Meeting, (Dizon TD, Eusebio JE, Duenas JN, Palis FV and Mabbayad MO eds.). Pest Management Council of the Philippine, Davao City, pp. 61-77. 